\title{
Ownership Concentration, Dividend Payout and Firm Performance: The Case of Malaysia
}

\author{
Irene Wei Kiong Ting ${ }^{\mathrm{a}}$ \\ Universiti Malaysia Pahang \\ Qian Long Kweh ${ }^{\mathrm{b}}$ \\ Canadian University Dubai \\ Kausalyaa Somosundaram ${ }^{c}$ \\ Universiti Tenaga Nasional
}

\begin{abstract}
This study examines how ownership concentration affects dividend payout, and ultimately firm performance. Regression analyses are performed on a dataset spanning 11 years (2005-2015) among Malaysian publicly listed firms. The results show that shareholders with concentrated ownership play an important role in determining dividend payout and driving firm performance. Specifically, ownership concentration is associated with low dividend payout, but it improves firm performance. Overall, this study suggests that ownership concentration may also be an effective monitoring mechanism.
\end{abstract}

Keywords: Agency theory, dividend payout, firm performance, ownership concentration JEL classification: G32, L25

\section{Introduction}

The purpose of this paper is to examine the impact of ownership concentration on dividend payout of Malaysian firms from an agency perspective. In the spirit of studying the severity of expropriation of minority shareholders in Malaysian public listed companies, this paper further analyses how ownership concentration influences firm performance.

In the agency theory context, studies (for an example, La Porta, Lopez-de-Silanes, Shleifer, \& Vishny, 2000) have revealed that dividend payout is used to prevent shareholders with power from diverting retained earnings for their own benefits. Although agency conflict between the managers and shareholders is less severe in closely-held firms, such firms deal with greater conflict on the relationship between majority and minority shareholders. Despite the usefulness of dividend payout in reducing the said agency problem, researches are mostly focused on countries with strong investor protection, but not those with weak investor protection (La Porta et al.,

a Faculty of Industrial Management, Universiti Malaysia Pahang, Lebuhraya Tun Razak, 26600 Gambang, Kuantan, Pahang, Malaysia. Email: irene@ump.edu.my (Corresponding author).

b Faculty of Management, Canadian University Dubai, P.O. Box 117781, 1st Interchange, Sheikh Zayed Road, Dubai, United Arab Emirates. Email: qlkweh@cud.ac.ae

c Department of Accounting, Universiti Tenaga Nasional, Sultan Haji Ahmad Shah Campus, 26700 Muadzam Shah, Pahang, Malaysia. Email: skausalyaa@yahoo.com 
2000). Besides, the trend of dividend payout varies not only across time but also across countries, especially between developed and developing countries.

Likewise, Malaysia has a different capital market integration, legal system, economic development and country credit risk (Fauver, Houston, \& Naranjo, 2003). Besides, the Asian financial crisis caused the Malaysian authorities to reform and restructure corporations rapidly, among which included strengthening corporate governance. Companies in Malaysia have also been reported to have highlyconcentrated ownership as compared with those in other Asian countries (Cheung, Stouraitis, \& Wong, 2005; Claessens, Djankov, \& Lang, 2000; Shang, Gao, \& Zhang, 2013). Problems associated with the high concentration of ownership and control in Malaysia include room for controlling shareholders to make less dividend payout decision. This is because they prefer to use the firm's money for their private benefits, resulting in severe large shareholders and minority shareholders' conflicts.

A key contribution of this study is that it sheds additional light on the inconclusive issues regarding the effects of ownership concentration on dividend payout, which is still unexplored in an emerging market like Malaysia. From here, investors can observe the opportunistic behaviour of controlling shareholders on how to screen and select the best suit stocks in building their portfolio. Numerous researches have been carried out to identify the unique characteristics of a firm and how it enhances dividend policy. However, the empirical significance of these studies remains largely unknown especially in terms of the relation between ownership concentration, dividend payout and firm performance. This paper fills the gap. Other contributions of this paper are as follows. First, this is the earliest study that empirically examines the impact of ownership concentration as a main independent variable on dividend payout and how dividend payout affects the firm performance in one go for Malaysian firms. Second, three measures of ownership concentration are employed in this study.

The next section provides a brief literature on ownership concentration, dividend payout and firm performance and the hyphotheses development. The following section is an explanation of the research method employed in this study, and analysis of the result in detail. Implications and conclusion are presented in the last section.

\section{Literature Review}

\subsection{Ownership Concentration and Dividend Payout}

In East Asian corporations, it is common that controlling shareholders have power primarily through the use of pyramids and participation in management. Controlling shareholders tend to exploit and seek personal benefits at the expense of minority shareholders, which lead to the agency problem (Claessens et al., 2000). Prior studies reveal that as ownership concentration increases, Malaysian firms tend to pay low dividends because concentrated shareholders can exploit the company resources and are unpunished for such misconduct. Mancinelli and Ozkan (2006) further claimed that ownership concentration may permit large shareholders to expropriate minority shareholders. In this way, dominant shareholders can act in their own best interest and exert their power to benefit themselves at the expense of minority shareholders 
by redistributing wealth among them. Hence, a negative relationship is found between the largest shareholder and dividend payout for companies from Germany and Italy as observed by Gugler and Yurtoglu (2003) and Mancinelli and Ozkan (2006), respectively. Some similar results were also provided by Gonzalez, Molina, Pablo, and Rosso (2017) for Latin America.

However, Easterbrook (1984) and Jensen (1986) proposed the idea that ownership concentration is a credible mechanism to reduce agency problems. De Cesari (2012) also agreed that ownership concentration is positively associated with dividend payout, which prevents the conflict between controlling and minority shareholders. Contrary to this, Andres, Betzer, Bongard, Haesner, and Theissen (2013) indicated that ownership concentration affects dividend payout, depending on the type of controlling shareholders among German firms. Based on the above discussions, the hypothesis is thus developed as follows:

$\mathrm{H}_{1}$ : Ownership concentration is significantly related to dividend payout.

\subsection{Ownership Concentration and Firm Performance}

Prior studies suggest that pursuing private benefits by large and dominant shareholders may lead to poor firm performance because private shareholder interests and firm interests may differ. Similarly, ownership concentration exerts a negative effect on the return on assets of firms. Kuznetsov, Kapelyushnikov, and Dyomina (2008) explained that controlling shareholders prefer to invest in low-risk or low-productive projects when they feel that their position is being threatened. Similarly, in Korea, Joh (2003) reveals that ownership concentration negatively affects firm profitability. Consistently, Basir Malan, Salamudin, and Ahmad (2015) argued that highly concentrated ownership is negatively associated with the performance of Malaysian firms due to expropriation of minority interest. However, from another school of thought, the researchers believe that there is a non-linear relationship between ownership concentration and firm performance. According to Ramli (2010) and Thanatawee (2012), when ownership is concentrated, firm performance tends to improve, but beyond a certain point, firm performance decreases because shareholders gain so much control that they can maximise their own welfare by using their voting powers. Similarly, Claessens et al. (2000) confirmed that ownership concentration initially exerts an increasing effect and then a decreasing effect on firm performance. However, Cronqvist and Mattias (2003) documented that ownership concentration and firm performance are not related in Swedish public listed firms. Therefore, the hypothesis is designed as follows:

$\mathrm{H}_{2}$ : Ownership concentration is significantly related to firm performance.

\section{Data and Methodology}

\subsection{Source of Data}

To form the sample, we first select all 811 companies that are listed on the Main Board of Bursa Malaysia as of 31 December 2015. After excluding finance, insurance and unit trust companies due to differences in regulatory requirement and data incompleteness, 
Table 1. Process of data collection

\begin{tabular}{lc}
\hline & $\begin{array}{c}\text { Number of } \\
\text { observations }\end{array}$ \\
\hline $\begin{array}{l}\text { Initial number of observations } \\
\text { 1) After selecting companies with continuous operations throughout the }\end{array}$ & 8,921 \\
sample period of 2005 to 2015. & 7,562 \\
2) After removing all companies from banking, finance, and real estate investment & \\
trust sectors, which were identified based on Bursa Malaysia classification & \\
from (www.malaysiastock.biz) to enhance the comparability of the sample. & 6,380 \\
3) After removing companies with missing data, incomplete information, or & \\
discontinuous operation in the sample period. & 5,584 \\
\hline
\end{tabular}

the total observation remains at 5,584 from 580 companies for the period from 2005 to 2015 . In accordance with the research purpose and to ensure data validity, the initial sample is screened according to the criteria as shown in Table 1.

\subsection{Model and Variables}

Two dependent variables are considered in the model for examining dividend payout and firm performance. Dividend payout (Div) is measured as the ratio of cash dividends to net profit (Feng, 2011; Kajola, Adewumi, \& Oworu, 2015). Firm Performance (Perf) is measured as the ratio of net profit after tax to shareholder's equity (ROE) (Bany-Ariffin, Mat Nor, \& McGowan Jr, 2010).

The independent variable, ownership concentration $(O C)$, is the portion of ordinary shares held by the block shareholders, including the portions held by the top largest, the top three largest and the top five largest shareholders, respectively, following Lean, Ting, and Kweh (2015).

The following control variables are also included in the model: (i) Firm leverage (Flev) is total liabilities divided by total assets; (ii) Firm liquidity (Fliq) is current assets divided by current liabilities (Paydar \& Bardai, 2012); (iii) Firm growth (Fgrowth) is change in total assets (Flint, Tan, \& Tian, 2010); (iv) Firm size (Fsize) is logged total assets (Beiner, Drobetz, Schmid, \& Zimmermann, 2006); (v) Firm age (Fage) is logged number of years of listing (Zunaidah \& Fauzias, 2008); (vi) Board size (Bsize) is logged number of board of directors (Farinha, 2003); (vii) Independent Director (INDDIR) is number of independent directors divided by the total number of directors (Johl, Kaur, \& Cooper, 2013); (viii) Board meetings (MEETINGS) is the number of board of director's meetings (Johl et al., 2013).

According to Shleifer and Vishny (1997) and Bebchuk, Kraakman, and Triantis (2000), when ownership is concentrated, the agency problem becomes more severe because the controlling shareholders tend to set a disclosure policy that allows them to conceal their diversion activities (Lang \& Lundholm, 1996; Leuz, Nanda, \& Wysocki, 2003). Thus, agency theory provides a framework on how to create an effective protection system to reduce the agency cost. As such, regression analysis is performed 
to investigate the impact of ownership concentration on dividend payout and firm performance. The following regressions are thus developed:

$$
\begin{aligned}
\text { Div }_{i t}= & \alpha_{0}+\alpha_{1} \text { OC }_{i t}+\alpha_{2} \text { Flev }_{i t}+\alpha_{3} \text { Fliq }_{i t}+\alpha_{4} \text { Fgrowth }_{i t}+\alpha_{5} \text { Fsize }_{i t}+\alpha_{6} \text { Fage }_{i t} \\
& +\alpha_{7} \text { Bsize }_{i t}+\alpha_{8} \text { INDDIR }_{i t}+\alpha_{9} \text { MEETINGS }_{i t}+\varepsilon_{i t} \\
\text { Perf }_{i t}= & \alpha_{0}+\alpha_{1} \text { OC }_{i t}+\alpha_{2} \text { Flev }_{i t}+\alpha_{3} \text { Fliq }_{i t}+\alpha_{4} \text { Fgrowth }_{i t}+\alpha_{5} \text { Fsize }_{i t}+\alpha_{6} \text { Fage }_{i t} \\
& +\alpha_{7} \text { Bsize }_{i t}+\alpha_{8} \text { INDDIR }_{i t}+\alpha_{9} \text { MEETINGS }_{i t}+\varepsilon_{i t}
\end{aligned}
$$

where $\alpha_{0}$ represents the constant terms in Equations 1 and 2, respectively; $i=1$ to 9 , are coefficients of the respective independent or control variables for Equations 1 and 2 , respectively; and $\varepsilon_{i t}$ represents error terms.

\section{Results and Analysis}

\subsection{Descriptive Statistics}

Table 2 presents the descriptive statistics of the variables used in the analysis. The univariate result shows that the sample companies use $38 \%$ of their net profit to pay cash dividends. The mean of OC 1 reveals that almost $30 \%$ of the company shares are held by the one largest shareholder. For $R O E$, the mean reveals that the sample

Table 2. Descriptive statistics

\begin{tabular}{lrrrrr}
\hline & $\mathrm{N}$ & Mean & Standard deviation & Minimum & Maximum \\
\hline Div & 5604 & 0.385 & 4.862 & -34.814 & 293.238 \\
OC 1 & 5584 & 0.295 & 0.164 & 0.000 & 0.992 \\
OC 3 & 5584 & 0.465 & 0.176 & 0.000 & 0.992 \\
OC 5 & 5584 & 0.517 & 0.183 & 0.174 & 0.999 \\
ROE & 5607 & 0.054 & 0.501 & -20.765 & 12.526 \\
Flev & 5584 & 0.423 & 0.373 & 0.003 & 13.148 \\
Fliq & 5584 & 6.967 & 102.312 & 0.000 & 4101.545 \\
Fsize & 5584 & 12.877 & 1.399 & 8.908 & 18.579 \\
Fgrowth & 5584 & 0.568 & 1.006 & 0.000 & 28.627 \\
Fage & 5584 & 2.375 & 0.804 & 0.000 & 3.989 \\
Bsize & 5584 & 1.954 & 0.247 & 0.693 & 2.890 \\
INDDIR & 5584 & 0.448 & 0.118 & 0.143 & 1.000 \\
MEETINGS & 5584 & 5.071 & 1.257 & 1.000 & 21.000 \\
\hline
\end{tabular}

Note: Div is the ratio of cash dividends to net profit; $R O E$ is the ratio of net profit after tax to shareholder's equity, the ratio of net profit after tax to total assets and net profit after tax to total outstanding shares, respectively; $O C$ is the percentage of common shares held by the top one largest shareholder $(O C 1)$, the top three largest shareholders $(O C 3)$ and the top five largest shareholders $(O C 5)$, respectively; Flev is the ratio of total liabilities to total assets; Fliq is the ratio of current assets to current liabilities; Fgrowth is the ratio of market value of firm to total asset; Fage is the natural logarithm of the number of years a company has since been listed; Fsize is the natural logarithm of total assets; Bsize is the natural logarithm of the number of directors in the board; INDDIR is the ratio of number of independent directors to the total number of directors; MEETINGS is the number of board of directors meetings held during a financial year. 
companies generate $5 \%$ profitability of the shareholders' investment in the company. Additionally, the mean of Bsize implies that seven directors are in the board on the average. INDDIR shows that almost $50 \%$ of the sample companies' board of directors are independent directors. The Flev mean explains that $42 \%$ of the company assets are financed by debt. The Fgrowth mean of 0.568 indicates that companies show positive economic growth.

\subsection{Regression Analysis}

Table 3 shows the pooled ordinary least squares $(O L S)^{1}$ regression results of using Div as the dependent variable. The F-statistic indicates the overall significance of the equations at the $5 \%$ significance level. The empirical evidence of Equation 1 depicts a significantly negative relationship between the top largest shareholder (OC 1) and Div. This finding is consistent with those of Benjamin and Pajuste (2011) and Guizani and Kouki (2011), indicating that ownership concentration is associated with a low level of dividend payout. This study performs robustness checks by replacing OC 1 with OC 3 and $O C 5$, respectively. The estimation results in Table 3 remain qualitatively the same, supporting that low levels of dividend payout are likely to be observed in firms with a high percentage of ownership concentration.

Table 3. Regression analysis - Equation 1

\begin{tabular}{lccc}
\hline Variables & \multicolumn{3}{c}{ Dependent variable: Div } \\
\hline Intercept & $1.790^{*}$ & $1.790^{*}$ & $1.692^{*}$ \\
OC 1 & $-1.055^{* *}$ & & \\
OC 3 & & $-0.642^{*}$ & \\
OC 5 & & & $-0.195^{*}$ \\
Flev & $-3.089^{* * *}$ & $-3.031^{* * *}$ & -2.964 \\
Fliq & 0.286 & 0.288 & 0.284 \\
Fgrowth & 1.032 & 0.964 & 0.907 \\
Fsize & 1.186 & 1.116 & 1.058 \\
Fage & 0.321 & 0.357 & 0.401 \\
Bsize & $-2.541^{* *}$ & $-2.526^{* *}$ & -2.504 \\
INDDIR & $-1.688^{*}$ & $-1.693^{*}$ & -1.67 \\
MEETINGS & 0.854 & 0.865 & 0.849 \\
$R^{2}$ & 0.006 & 0.005 & 0.005 \\
Adjusted $R^{2}$ & 0.003 & 0.003 & 0.003 \\
F-statistics & $2.141^{* *}$ & $2.062^{* *}$ & $2.020^{* *}$ \\
\hline
\end{tabular}

Note: $*, * *$, and $* * *$ denote statistical significance at the $10 \%, 5 \%$, and $1 \%$ levels, respectively.

1 Diagnostic tests (not reported) indicate that the fixed ( $F$ test) or random effects (Hausman test) panel methods are redundant, suggesting that the extent of within-panel correlation of observations is negligibly small. Therefore, the OLS regression results provide consistent estimations in this study. Besides, we find no heteroscedasticity problem. 
As for the control variables, Flev, Bsize, and INDDIR have a significant negative relationship with dividend payout. These results are consistent with those of Benjamin and Pajuste (2011) and Ghasempour and Vakilifar (2015), who explained that high leverage means the firm is highly risky in cash flow and pays low dividends to evade the cost of raising external capital.

Table 4 shows the OLS regression results of using ROE as the dependent variable. The F-statistics indicates the overall significance of the equations at the $1 \%$ significance level. The empirical evidence of Equation 2 depicts a significantly positive relationship between top largest shareholder's ownership (OC 1) and firm performance (ROE). This finding is consistent with those of Ma, Naughton, and Tian (2010) and Lepore, Paolone, Pisano, and Alvino (2017) who supported that controlling shareholders can implement effective monitoring activities on the management and other controlling shareholders who may have different objectives toward the firm. Hence, companies with ownership concentration appear to be an effective internal corporate governance mechanism that helps enhance performance. The robustness test with $O C 3$ and $O C 5$ also show consistent findings, whereby ownership concentration has a significantly positive relation with firm performance.

The other variables for Equation 2, Fgrowth, Fsize, and Bsize show a significantly positive relationship with firm performance $(R O E)$, consistent with the findings of Uwuigbe, Jafaru, and Ajayi (2012) and Ghasempour and Vakilifar (2015). Meanwhile, Flev, Fage, and Bsize have a significant negative relation with $R O E$, similar to the findings of Rehman and Hussain (2013) and Velnampy, Nimalthasan, and Kalaiarasi (2014). Fliq, MEETINGS and INDDIR show an insignificant relationship with firm performance.

Table 4. Regression analysis - Equation 2

\begin{tabular}{lccc}
\hline Variables & \multicolumn{3}{c}{ Dependent variable: $R O E$} \\
\hline Intercept & $2.990^{* *}$ & $2.905^{* *}$ & $1.847^{*}$ \\
OC 1 & $2.695^{* * *}$ & & \\
OC 3 & & $1.664^{*}$ & \\
OC 5 & & & $1.431^{*}$ \\
Div & $38.813^{* * *}$ & $38.761^{* * *}$ & $38.745^{* * *}$ \\
Flev & $-4.270^{* * *}$ & $-4.130^{* * *}$ & $-4.080^{* * *}$ \\
Fliq & -1.438 & -1.441 & -1.431 \\
Fgrowth & $36.903^{* * *}$ & $37.147^{* * *}$ & $37.261^{* * *}$ \\
Fsize & $2.654^{* * *}$ & $2.846 * * *$ & $2.914^{* * *}$ \\
Fage & $-4.818^{* * *}$ & $-4.899 * * *$ & $-4.908^{* *}$ \\
Bsize & $-2.428^{* *}$ & $-2.462^{* * *}$ & $-2.482^{* *}$ \\
INDDIR & -0.928 & -0.917 & -0.908 \\
MEETINGS & -1.742 & -1.768 & -1.760 \\
$R^{2}$ & 0.476 & 0.475 & 0.475 \\
Adjusted $R^{2}$ & 0.474 & 0.473 & 0.473 \\
F-statistics & $307.682^{* * *}$ & $306.826 * * *$ & $306.689 * * *$ \\
\hline
\end{tabular}

Note: $* * *$, and $* * *$ denote statistical significance at the $10 \%, 5 \%$, and $1 \%$ levels, respectively. 


\subsection{Discussion}

Overall, the results of the regression analyses above indicate that in Malaysia, companies with a high degree of ownership concentration are less likely to pay dividend because the majority shareholders prefer to use the cash flow to invest in different projects that are profitable for them. The existence of a reverse relationship between ownership concentration in the hands of the largest shareholder and the amount of dividends paid is a manifestation of the agency problem between major and minority shareholders. Second, ownership concentration also enhances the profitability of the company as it supports the agency perspective that ownership concentration appears to be an effective internal corporate governance strategy that helps enhance performance.

As an additional test to verify the validity of our results, we further examine whether firm performance is significantly related to dividend payout. It is well documented in prior studies that firm performance is positively associated with the dividend payout of firms. On one hand, Waithaka, Ngugi, and Kirago (2012) discovered that firm performance is negatively influencing dividend payout in Kenyan firms. On the other hand, Amidu and Abor (2006) identified a positive and significant relationship between firm performance and dividend payout. They further justified that dividend payout is an essential element in reflecting the performance of a company to shareholders and potential investors. Meanwhile, Arnott and Asness (2003) pointed out that the suboptimal investment and less-than-ideal projects by managers with excess free cash flows at their disposal cause low dividend, which leads to low growth. Hence, they concluded that there is a positive relationship between current dividend payout and future earnings growth according to free cash flow theory. This situation is prominent in firms with limited growth opportunities or a tendency toward over-investment. Paying substantial dividends, which in turn would require managers to raise funds from the issuance of shares and reduce conflicts of interest, may subject the management to significant scrutiny and thus curtail suboptimal investment (Jabbouri, 2016).

Therefore, the relationship between firm performance and dividend payout is also examined. Table 5 presents the regression analysis results of using Div as the dependent variable. The F-statistics indicate the overall significance of the equations at the $1 \%$ significance level. The results depict a significantly positive relationship between $R O E$ and Div. This finding is consistent with Guizani and Kouki (2011). The positive effect of $R O E$ on dividend payout remains quantitively the same when the study replaces $R O E$ with $R O A$ and EPS, respectively. ROA is the ratio of net profit after tax to total assets, while EPS is net profit after tax to total outstanding shares. The results of Table 5 confirm the existence of a positive association between the firm performance and dividend payout. For the control variables, the finding shows that only Fliq, Fage, and MEETINGS have a significantly positive relationship with Div. Meanwhile, Flev, Fgrowth, and Fsize have a significant negative relationship with dividend payout. This result is consistent with those of Benjamin and Pajuste (2011) and Ghasempour and Vakilifar (2015). The significant coefficients of firm performance confirm that the results of this study are in line with prior studies and thus provide support for the empirical results of Equations 1 and 2. 
Table 5. Regression analysis - Additional test

\begin{tabular}{lccc}
\hline Variables & \multicolumn{3}{c}{ Dependent variable: Div } \\
\hline Intercept & $2.721^{* *}$ & $2.374^{* *}$ & $9.267^{* * *}$ \\
ROE & $38.735^{* * *}$ & & \\
ROA & & $87.061^{* * *}$ & \\
EPS & & & $45.068^{* * *}$ \\
Flev & $-4.638^{* * *}$ & $-6.817^{* * *}$ & -1.131 \\
Fliq & $2.299^{* *}$ & $2.698^{* * *}$ & 1.206 \\
Fgrowth & $-17.639^{* * *}$ & $-24.082^{* * *}$ & $-13.153^{* * *}$ \\
Fsize & $-1.936^{*}$ & $-2.363^{* *}$ & $-9.027^{* * *}$ \\
Fage & $3.171^{* *}$ & $7.580^{* * *}$ & -0.306 \\
Bsize & -0.667 & -0.635 & $-2.260^{* *}$ \\
INDDIR & -0.823 & -1.125 & $-3.047^{* *}$ \\
MEETINGS & $1.650^{*}$ & $1.989^{* *}$ & 1.203 \\
$R^{2}$ & 0.31 & 0.692 & 0.378 \\
Adjusted $R^{2}$ & 0.309 & 0.692 & 0.376 \\
F-statistics & $169.618^{* * *}$ & $848.700^{* * *}$ & $228.908^{* * *}$ \\
\hline
\end{tabular}

Note: ${ }^{*}, * *$, and ${ }^{* * *}$ denote statistical significance at the $10 \%, 5 \%$, and $1 \%$ levels, respectively.

\section{Conclusion}

This study investigates the effect of ownership concentration on dividend payout and firm performance, as well as the association between firm performance and dividend payout as a validity check. This paper analyses a sample of 580 publicly listed Malaysian firms over the period 2005-2015 and try to answer two questions. First and most importantly, does concentrated ownership affect dividend payout? The empirical analysis shows a negative relationship between ownership concentration and dividend payout. The results demonstrate that a high degree of ownership concentration is less likely to pay dividend because the majority shareholders prefer to use the cash flow to invest in different projects that are profitable for them, rather than pay dividend to the minority shareholders. This finding is consistent with those of Gugler and Yurtoglu (2003), Mancinelli and Ozkan (2006), Renneboog and Trojanowski (2007), Berezinets, Ilina, and Alekseeva (2014), and Al-Najjar and Kilincarslan (2016).

Second, does ownership concentration affect firm performance? This paper finds a positive relationship between ownership concentration and firm performance as the shareholders can implement effective monitoring activities on the management and other controlling shareholders who may have different objectives toward the firm. These findings are aligned with those of Chen, Cheung, Stouraitis, and Wong (2005), Heugens, Van Essen, and van Oosterhout (2009), Harada and Nguyen (2011), Ma et al. (2010), and Balsmeier and Czarnitzki (2015). This study helps to create guidelines for the relevant policy makers to plan and design policies that will suit the Malaysian business environment as it shows that there is a need to strengthen the policy to protect minority shareholders in Malaysia. Notably, this study does not separate the 
type of shareholders as moderating variables and the samples are obtained only from the main market of Bursa Malaysia.

Therefore, future research may consider different types of shareholders and use samples from different sources. Besides, future research should also consider studying the trend of dividend payout during different economic situations because companies might pay different levels of dividends in bad economic situations. Finally, while this study provides supplementary confirmation that ownership concentration is an important factor of dividend payout, we caution readers that the findings may not be generalised beyond emerging markets.

\section{References}

Al-Najjar, B., \& Kilincarslan, E. (2016). The effect of ownership structure on dividend policy: Evidence from Turkey. Corporate Governance: The International Journal of Business in Society, 16(1), 135-161. https://doi.org/10.1108/CG-09-2015-0129

Amidu, M., \& Abor, J. (2006). Determinants of dividend payout ratios in Ghana. The Journal of Risk Finance, 7(2), 136-145. https://doi.org/10.1108/15265940610648580

Andres, C., Betzer, A., Bongard, I., Haesner, C., \& Theissen, E. (2013). The information content of dividend surprises: Evidence from Germany. Journal of Business Finance \& Accounting, 40(56), 620-645. doi: 10.1111/jbfa.12036

Arnott, R.D., \& Asness, C.S. (2003). Surprise! Higher dividends = Higher earnings growth. Financial Analysts Journal, 59(1), 70-87. http://dx.doi.org/10.2469/faj.v59.n1.2504

Balsmeier, B., \& Czarnitzki, D. (2015). Ownership concentration, institutional development and firm performance in Central and Eastern Europe. Managerial and Decision Economics, 38(2), 178-192. doi: 10.1002/mde.2751

Bany-Ariffin, A.N., Mat Nor, F., \& McGowan Jr, C.B. (2010). Pyramidal structure, firm capital structure exploitation and ultimate owners' dominance. International Review of Financial Analysis, 19(3), 151-164. https://doi.org/10/1016/j.irfa.2010.03.002

Basir Malan, I.N., Salamudin, N., \& Ahmad, N. (2015). Length of chain in pyramidal firms towards expropriation of minority interest. International Business Research, 8(4), 303-316. http:// dx.doi.org/10.5539/ibr.v8n4p303

Bebchuk, L.A., Kraakman, R., \& Triantis, G. (2000). Stock pyramids, cross-ownership, and dual class equity: The mechanisms and agency costs of separating control from cash-flow rights. In R.K. Morck (Ed.), Concentrated corporate ownership (pp. 295-318). Chicago, IL: University of Chicago Press.

Beiner, S., Drobetz, W., Schmid, M.M., \& Zimmermann, H. (2006). An integrated framework of corporate governance and firm valuation. European Financial Management, 12(2), 249-283. doi: 10.1111/j.1354-7798.2006.00318.x

Benjamin, M., \& Pajuste, A. (2011). Multiple large shareholders and firm value. Journal of Banking \& Finance, 29(7), 1813-1834.

Berezinets, I., Ilina, Y., \& Alekseeva, L. (2014). Dividends on common and preferred shares: The relationship with the ownership concentration in Russian public companies. Journal of Economic and Social Development, 1(2), 48-59.

Chen, Z., Cheung, Y.-L., Stouraitis, A., \& Wong, A.W. (2005). Ownership concentration, firm performance, and dividend policy in Hong Kong. Pacific-Basin Finance Journal, 13(4), 431449. https://doi.org/10/1016/j.pacfin.2004.12.001

Cheung, Y.-L., Stouraitis, A., \& Wong, A.W.S. (2005). Ownership concentration and executive compensation in closely held firms: Evidence from Hong Kong. Journal of Empirical Finance, 12(4), 511-532. https://doi.org/10.1016/j.jempfin.2004.10.001 
Claessens, S., Djankov, S., \& Lang, L.H.P. (2000). The separation of ownership and control in East Asian Corporations. Journal of Financial Economics, 58(1-2), 81-112. doi: 10.1016/S0304405X(00)00067-2

Cronqvist, H., \& Mattias, N. (2003). Agency costs of controlling minority shareholders. The Journal of Financial and Quantitative Analysis, 38(4), 695-719. doi: 10.2307/4126740

De Cesari, A. (2012). Expropriation of minority shareholders and payout policy. The British Accounting Review, 44(4), 207-220. https://doi.org/10.1016/j.bar.2012.09.002

Easterbrook, F.H. (1984). Two agency-cost explanations of dividends. The American Economic Review, 74(4), 650-659.

Farinha, J. (2003). Dividend policy, corporate governance and the managerial entrenchment hypothesis: An empirical analysis. Journal of Business Finance \& Accounting, 30(9-10), 11731209. doi: 10.1111/j.0306-686X.2003.05624.x

Fauver, L., Houston, J., \& Naranjo, A. (2003). Capital market development, international integration, legal systems, and the value of corporate diversification: A cross-country analysis. The Journal of Financial and Quantitative Analysis, 38(1), 135-157. doi: 10.2307/4126767

Feng, X. (2011). Dividends and tunneling: Evidence from family firms in China. China Finance Review International, 1(2), 152-167. https://doi.org/10.1108/20441391111100732

Flint, A., Tan, A., \& Tian, G.G. (2010). Predicting future earnings growth: A test of the dividend payout ratio in the Australian market. The International Journal of Business and Finance Research, 4(2), 43-58.

Ghasempour, K., \& Vakilifar, H. (2015). Investigation the impact of financial leverage and financial performance on the dividend policy among companies listed on the Tehran stock exchange. International Journal of Review in Life Sciences, 5(9), 1285-1291.

Gonzalez, M., Molina, C.A., Pablo, E., \& Rosso, J.W. (2017). The effect of ownership concentration and composition on dividends: Evidence from Latin America. Emerging Markets Review, 30(March), 1-18. https://doi.org/10.1016/j.ememar.2016.08.018

Gugler, K., \& Yurtoglu, B.B. (2003). Corporate governance and dividend pay-out policy in Germany. European Economic Review, 47(4), 731-758.

Guizani, M., \& Kouki, M. (2011). Ownership-control discrepancy and dividend policy: Evidence from Tunisia. International Business Research, 5(1), 127-139. http://dx.doi.org/10.5539/ibr. v5n1p127

Harada, K., \& Nguyen, P. (2011). Ownership concentration and dividend policy in Japan. Managerial Finance, 37(4), 362-379. https://doi.org/10.1108/03074351111115313

Heugens, P.P., van Essen, M., \& van Oosterhout, J.H. (2009). Meta-analyzing ownership concentration and firm performance in Asia: Towards a more fine-grained understanding. Asia Pacific Journal of Management, 26(3), 481-512. doi: 10.1007/s10490-008-9109-0

Jabbouri, I. (2016). Determinants of corporate dividend policy in emerging markets: Evidence from MENA stock markets. Research in International Business and Finance, 37(May), 283298. doi: 10.1016/j.ribaf.2016.01.018

Jensen, M.C. (1986). Agency costs of free cash flow, corporate finance, and takeovers. The American Economic Review, 76(2), 323-329.

Joh, S.W. (2003). Corporate governance and firm profitability: Evidence from Korea before the economic crisis. Journal of Financial Economics, 68(2), 287-322. https://doi.org/10/1016/ S0304-405X(03)00068-0

Johl, S.K., Kaur, S., \& Cooper, B.J. (2013). Board characteristics and firm performance: Evidence from Malaysian public listed firms. Journal of Economics, Business and Management, 3(2), 239-243. doi: 10.7763/JOEBM.2015.V3.187

Kajola, S.O., Adewumi, A.A., \& Oworu, O.O. (2015). Dividend pay-out policy and firm financial performance: Evidence from Nigerian listed non-financial firms. International Journal of Economics, Commerce and Management, III(4), 1-13. 
Kuznetsov, A., Kapelyushnikov, R., \& Dyomina, N. (2008). Performance of closely held firms in Russia: Evidence from firm-level data*. The European Journal of Finance, 14(4), 337-358. http://dx.doi.org/10.1080/13518470802041924

La Porta, R., Lopez-de-Silanes, F., Shleifer, A., \& Vishny, R.W. (2000). Agency problems and dividend policies around the world. The Journal of Finance, 55(1), 1-33. doi: 10.1111/0022-1082.00199

Lang, M. H., \& Lundholm, R. J. (1996). Corporate disclosure policy and analyst behavior. The Accounting Review, 71(4), 467-492.

Lean, H.H., Ting, I.W.K., \& Kweh, Q.L. (2015). Ownership concentration, family ownership and leverage: Evidence from Malaysia. Malaysian Journal of Economic Studies, 52(2), 117-133.

Lepore, L., Paolone, F., Pisano, S., \& Alvino, F. (2017). A cross-country comparison of the relationship between ownership concentration and firm performance: Does judicial system efficiency matter? Corporate Governance: The International Journal of Business in Society, 17(2), 321340. https://doi.org/10.1108/CG-03-2016-0049

Leuz, C., Nanda, D., \& Wysocki, P.D. (2003). Earnings management and investor protection: An international comparison. Journal of Financial Economics, 69(3), 505-527. https://doi. org/10.1016/S0304-405X(03)00121-1

Ma, S., Naughton, T., \& Tian, G. (2010). Ownership and ownership concentration: Which is important in determining the performance of China's listed firms? Accounting \& Finance, 50(4), 871-897. doi: 10.1111/j.1467-629X.2010.00353.x

Mancinelli, L., \& Ozkan, A. (2006). Ownership structure and dividend policy: Evidence from Italian firms. The European Journal of Finance, 12(3), 265-282. http://dx.doi.org/10.1080/ 13518470500249365

Paydar, M., \& Bardai, B. (2012). Leverage behavior of Malaysian manufacturing companies: A case observation of the industrial sector's companies in Bursa Malaysia. International Research Journal of Finance and Economics, 90(May), 54-65.

Ramli, N.M. (2010). Ownership structure and dividend policy: Evidence from Malaysian companies. International Review of Business Research Papers, 6(1), 170-180.

Rehman, M.U., \& Hussain, A. (2013). Impact of dividend policy on performance of firms having stocks listed in an emerging stock market. Asian Journal of Empirical Research, 3(1), 20-29.

Renneboog, L., \& Trojanowski, G. (2007). Control structures and payout policy. Managerial Finance, 33(1), 43-64. https://doi.org/10.1108/03074350710715809

Shang, C.-I., Gao, J., \& Zhang, H. (2013). The impact of separation of control and cash flow rights on diversification-Evidence from China. International Journal of Finance and Accounting Studies, 1(2), 9-16. doi: 10.7575/aiac.ijfas.v.1n.2p.9

Shleifer, A., \& Vishny, R.W. (1997). A survey of corporate governance. The Journal of Finance, 52(2), 737-783.

Thanatawee, Y. (2012). Ownership structure and dividend policy: Evidence from Thailand. International Journal of Economics and Finance, 5(1), 121-132. http://dx.doi.org/10.5539/ijef. v5n1p121

Uwuigbe, U., Jafaru, J., \& Ajayi, A. (2012). Dividend policy and firm performance: A study of listed firms in Nigeria. Accounting and Management Information Systems, 11(3), 442-454.

Velnampy, T., Nimalthasan, M.P., \& Kalaiarasi, M.K. (2014). Dividend policy and firm performance: Evidence from the manufacturing companies listed on the Colombo stock exchange. Global Journal of Management and Business Research, 14(6), 63-67.

Waithaka, S.M., Ngugi, J.K., \& Kirago, P. (2012). Effects of dividend policy on share prices: A case of companies in Nairobi Securities Exchange. Prime Journal of Business Administration and Management (BAM), 2(8), 642-648.

Zunaidah, S., \& Fauzias, M.N. (2008). Dividends, ownership structure and board governance on firm value: Empirical evidence from Malaysian listed firms. Malaysian Accounting Review, 7(2), 55-94. 